\begin{tabular}{|l|c|c|c|c|}
\hline $\begin{array}{l}\text { Cuadernos de Investigación Geográfica } \\
\text { Geographical Research Letters }\end{array}$ & 2019 & N $^{\circ} 45(2)$ & pp. 533-549 & eISSN 1697-9540 \\
\hline
\end{tabular}

\title{
HABITAT QUALITY ASSESSMENT OF ATLANTIC WET HEATHLANDS IN SERRA DO XISTRAL, NW SPAIN
}

\author{
C.V. MUÑOZ-BARCIA ${ }^{1}$, L. LAGOS ${ }^{1}$, C.A. BLANCO-ARIAS ${ }^{2}$, \\ R. DÍAZ-VARELA ${ }^{2}$, J. FAGÚNDEZ ${ }^{1 *}$ \\ ${ }^{1}$ Departamento de Biología, Facultad de Ciencias and Centro de Investigaciones Científicas \\ Avanzadas (CICA), Universidade da Coruña, 15071 A Coruña, Spain. \\ ${ }^{2}$ Departamento de Botánica, Escola Politécnica Superior, GI-1809-BioAplic, \\ Universidade de Santiago de Compostela, 27002 Lugo, Spain.
}

\begin{abstract}
The assessment of habitat quality, especially in semi-natural managed systems, provides a powerful tool for monitoring short and longterm conservation actions. The Erica mackayana Atlantic wet heathlands of the Serra do Xistral protected area in Galicia, NW Spain, represent a dynamic system with high conservation value associated to traditional management through grazing of free-ranging cattle and wild ponies. Here, we aimed to develop a spatially-explicit, quantitative method for Habitat Quality Assessment, defining an optimum state and the alternative states that may arise from habitat degradation. Vegetation structure, grass-shrub cover ratio, gorse cover, presence of bracken, exotic species such as pine trees and saplings, erosive events and altered hydrological dynamics were identified as the main indicators of habitat degradation. A heterogeneous vegetation structure with a dominant shrub cover of c.a. $0.5 \mathrm{~m}$ height and constant gaps among shrubs, with a limited cover of gorse and absence of pine trees, bramble and bracken, and absence of erosive events was recognized as the optimum state. We applied the Habitat Quality Assessment (HQA) method to a pilot area within the Xistral protected site. Wet heathland was the dominant habitat, covering $37.1 \%$ of the area. $7.0 \%$ of the assessed heathlands were recognized as in the optimum state for habitat quality. Recommendations are made for habitat management to revert low scores, mainly by the adjustment of livestock numbers and the removal of exotic pine trees.
\end{abstract}

\section{Evaluación de la calidad de hábitats de brezales húmedos atlánticos en la Serra do Xistral, NO España}

RESUMEN. La evaluación de la calidad de hábitats constituye una herramienta muy útil para el seguimiento, a medio y largo plazo, de las acciones de conservación, especialmente en sistemas semi-naturales manejados. Los brezales húmedos atlánticos con Erica mackayana del espacio Red Natura Serra do Xistral, situado en Galicia, noroeste de España, representan un sistema dinámico con alto valor de conservación asociado al manejo tradicional mediante 
ganado vacuno y caballos salvajes. En este artículo desarrollamos un método cuantitativo y espacialmente explícito para la evaluación de la calidad del hábitat en brezales húmedos. Para ello definimos un estado óptimo y los estados alternativos que pueden resultar de la degradación del hábitat. Los principales indicadores de degradación que identificamos fueron la estructura de la vegetación, la proporción de cobertura de herbáceas-arbustivas, la cobertura de tojo, la presencia de helechos (Pteridium aquilinum), especies exóticas como los pinos, eventos erosivos y la existencia de dinámicas hidrológicas alteradas. El estado óptimo se definió como una estructura de la vegetación heterogénea, con una cobertura de arbustivas dominante de entorno a $0,5 \mathrm{~m}$ de alto y pasillos constantes entre las matas, con cierta cobertura de tojo, ausencia de pinos, helechos, eventos erosivos y alteraciones hidrológicas. Aplicamos la Evaluación de la Calidad de Hábitats a un área piloto dentro del espacio Serra do Xistral. Los brezales húmedos son el hábitat dominante y cubren el 37,1\% del área de estudio. Un 7,0\% de los brezales evaluados puntuaron como en estado óptimo. Se incluyen una serie de recomendaciones de manejo que permitan incrementar los valores de calidad de hábitats, ajustando la presión de ganado o la retirada de especies exóticas como el pino.

Key words: Habitat Quality Assessment, Atlantic wet heathlands, semi-natural habitats, vegetation, conservation.

Palabras clave: evaluación de la calidad del hábitat, brezales húmedos atlánticos, hábitats semi-naturales, conservación.

Received: 7 June 2018

Accepted: 16 October 2018

*Corresponding author: Jaime Fagúndez, Departamento de Biología, Facultad de Ciencias and Centro de Investigaciones Científicas Avanzadas (CICA). Universidade da Coruña, 15071 A Coruña, Spain.E-mail address: jaime.fagundez@udc.es

\section{Introduction}

Habitat quality can be defined as the degree of departure of a given stand from an optimum state. The optimum state, or target, must be set according to quantitative and qualitative indicators of species composition and diversity, community structure, biotic interactions and overall ecological function (Hellawell, 1991). Habitat quality is thus a complex concept that relies on the strength of the knowledge of a particular system. In semi-natural habitats, those that are maintained by a certain degree of disturbance, describing the target is even more difficult. Semi-natural habitats are commonly subjected to human use. Therefore, the role of management is essential to maintain the habitat condition and quality (Vandvik et al., 2005). In accordance, the main task in habitat conservation for these systems is setting appropriate levels of management to achieve the target. Spatial and temporal dynamics are also a key issue in defining the conservation status of managed habitats. Indeed, a balanced distribution of patches with different 
development stages is commonly acknowledged as an ideal scenario maximizing the habitat resilience and biodiversity at the landscape scale (Gimingham, 1975).

Different methodologies exist for Habitat Quality Assessment (HQA), which address the condition of natural vegetation for monitoring potential changes in the long term. In terrestrial environments, HQA are based on physiognomic structure of the vegetation, floristics, diversity indexes, ecosystem functioning proxies and different indicators of habitat degradation (Parkes et al., 2003; Gibbons and Freudenberger, 2006). The main caveats are generally the lack of background information, the subjectivity of the methodology and the difficulties for its implementation. Ideally, HQA schemes should cover some general points addressed in Table 1.

Table 1. Requirements of a Habitat Quality Assessment (HQA) system.

HQA must be explicit and spatially located.

HQA may be set at different scales. Heterogeneity at larger scales including different states may improve the overall value.

HQA must be set regionally, but adjusted locally. For example, an indicator species may not naturally reach a certain altitude within the range of the habitat.

HQA should be based on a strong scientific knowledge, but keep scientific jargon to a minimum in the forms.

HQA should take into account the intrinsic dynamics of the habitat at landscape scale.

HQA must be set by using as many bio and geoindicators as possible, but the final system should include a limited number for feasibility.

Regarding conservation state assessment, the European Union Council Directive 92/43/EEC (Habitat Directive) imposes to all the EU Member States the evaluation and monitoring of habitats and species important for biodiversity listed in the Annexes II, IV and V. Besides, the EU Member States have to report periodically (every 6 years) the conservation status of the Directive Habitats of Interest. Even though the conservation status should be reported in a given format, Member States are free to use different means and methods for data collection and analysis. This information aims at ascertaining if a given habitat has reached a Favourable Conservation Status across the EU in terms of its area, structure and functions, as well as range and future prospects.

European Atlantic heathlands are semi-natural communities with a high proportion of shrub cover. They are (co)dominated by ericaceous species (Calluna vulgaris and Erica spp.), with a variety of other shrub species such as gorse (Ulex spp.), grasses and sedges and some herbs. They develop under poor-nutrient, mainly acid soils within a wide range of soil humidity. They occur in a wide geographical area, altitudinal range and soil conditions, but the similarities on the structure and composition of Atlantic heathlands is remarkable (Loidi et al., 2010). The human management throughout its distribution range has many common features such as the use of burning cutting and mowing, a constant in most regions, and the presence of domestic or free ranging herbivores (Webb, 1998; García et al., 2013 ). 
Lately, the importance of the Atlantic heathlands has been highlighted for its natural values for flora and fauna, and they are included within the Habitat Directive. Provision of ecosystem services include habitat for rare species, aesthetic value, recreation, carbon stock, water supply and many others (Morán-Ordóñez et al., 2013; Alonso and Hardtle, 2015; Cordingley et al., 2015). However, heathlands are in a continuous decline, and many rare species associated to this habitat are considered endangered (Hooftman et al., 2016). Heathland remnants in northern countries are now maintained for conservation purposes only, declared as natural reserves. For example, in the UK, the remaining heathlands is a scarce representation of the heaths occupancy at the beginning of the $20^{\text {th }}$ century, but most of the remaining heathlands are included in protected areas and efforts are directed to restore lost heathlands throughout the country (e.g. Pywell et al., 2011).

In this study, we have developed and tested a new HQA specific for Erica mackayana wet heaths in northern Galicia, but which may be adapted to other similar communities of temperate Europe. We aim to classify the wet heaths on this area according to its quality, to detect the main environmental problems of the habitat and to explore the health of this priority habitat in the region. Based on these results, we give some recommendations to recover a higher quality value for each item.

\section{Methods}

\subsection{Target habitat}

The E. mackayana wet heaths from northern Galicia occurs in a wide oceanic belt in northern Galicia, with a core area in the Xistral mountains, a protected Natura 2000 site of 22,964 ha (Consellería de Medio Ambiente, Territorio e Vivienda, 2018). In this area, heaths are commonly used as rangeland for cattle and wild ponies, more rarely for sheep (Fagúndez, 2016). The wild ponies of Serra do Xistral belong to the group of Atlantic Ponies that live in the north of the Iberian Peninsula (Bárcena, 2012) and have their largest population in the mountains of Galicia (Nuñez et al., 2016). This pony population is subjected to a traditional management system of great cultural significance (Nuñez et al., 2016). Ponies live free in the mountain throughout the year, but are rounded up once or twice a year in a typical event called "curro" or "rapa das bestas" mainly to fire brand them, share their mane and tail, and take the foals for meat (Iglesia, 1973; Bárcena, 2012; Lagos, 2013). Their positive influence on the structure and diversity of the Atlantic wet heathlands of E. mackayana has been demonstrated (Fagúndez, 2016). The main threats to the habitat is afforestation by exotic species, mainly Eucalyptus spp. and Pinus spp., transformation to improved pastures through ploughing, liming and seed addition of commercial species, and abandonment of traditional grazing practices. Effects of potential drivers such as climate change and atmospheric nitrogen deposition are not yet well understood in the region, but the strong dependence of the habitat on climatic conditions such as predominant cloud cover in summer suggest it can be a serious threat in the near future (Holden et al., 2007). 


\subsection{Defining items for habitat quality}

According to the literature and previous research, we have identified seven items relevant to habitat quality (Table 2):

- Vegetation structure. The typical structure of the E. mackayana heathlands is monotonous at the landscape scale, but heterogeneous at the fine scale (DíazVarela et al., 2018; Fagúndez, 2018). It can be recognized as a treeless habitat that occurs in large patches, where shrub mats alternate with gaps of herbaceous species or even bare ground (Fagúndez, 2016). Whenever this structure is lost, e.g. when grazing is abandoned in a given area, the vegetation grows taller and more homogeneous, and indicators such as species richness and diversity decrease (Fagúndez, 2016). Therefore, canopy height and vegetation heterogeneity are considered key features of habitat quality.

- Shrub-grass ratio. The flora of the E. mackayana heathlands is balanced between grasses, sedges and shrubs. In addition, there are a number of forbs in the community, some of which are recognized as declining species throughout Europe, and others are geographically restricted plants (Fagúndez, 2013,2016). A balanced proportion of the main groups of shrubs and graminoids is desirable (Fagúndez, 2018).

- Gorse cover. Gorse (mainly Ulex gallii) is a common shrub species within the E. mackayana heaths. However, in certain management situations, it may become dominant and the equilibrium between gorse and ericoid species such as E. mackayana or Calluna vulgaris is lost. Tall and dense gorse cover is an intermediate stage in the succession that may facilitate encroachment of shrub and trees, leading to the undesirable situation of heathland habitat replacement.

- Bracken cover. The presence of bracken (Pteridium aquilinum) is not frequent, and generally occurs when heathland is recovering in disturbed sites (Marrs, 1987). Therefore, it can be considered a low-quality indicator, although patches of bracken can be positive for some species and enhance micro-habitat diversity.

- Exotic tree species. Presence of seedlings or saplings of exotic pines (Pinus radiata, P. sylvestris, P. pinaster) or eucalyptus (Eucalyptus globulus, E. nitens) from nearby plantations can promote tree colonization, one of the main drivers of heathland loss.

- Natural succesion. Changes in the species composition from open heaths to woodlands trough sucessional processes constitute a main concern for the conservation of heathlands (Marrs et al., 1986). Species like bramble (Rubus sp.), tall shrubs like Erica arborea, and young deciduous trees become frequent, triggering the process of natural sucesion.

- Erosive features and drainage problems. Overgrazing or construction work may cause the loss of vegetation cover and the subsequent soil erosion by runoff (Bokdam et al., 2000; Díaz-Varela et al., 2018). Alteration of hydrological dynamics due to different infrastructures such as paved roads are commonly associated to erosive events in areas with steep slopes. 
Table 2. Habitat Quality Assessment items. For each item, measured indicators, description of the optimum value and alternative state, as well as recommendations to improve the score, are indicated. Each letter indicates which item does not reach the optimum. The first and second items show the direction of the departure from the optimum with $a+$ or - sign.

\begin{tabular}{|c|c|c|c|c|}
\hline Item & Measure & Optimum Value & Alternative status & $\begin{array}{c}\text { Recommenda- } \\
\text { tion }\end{array}$ \\
\hline \multirow{2}{*}{$\begin{array}{l}\text { Vegetation } \\
\text { structure }\end{array}$} & \multirow{2}{*}{$\begin{array}{l}\text { Canopy height at } \\
\text { regular intervals. }\end{array}$} & \multirow{2}{*}{$\begin{array}{l}\text { Shrub mats of } \\
0.3-0.6 \mathrm{~m} \text { and } \\
\text { gaps of }<0.1 \mathrm{~m} .\end{array}$} & $\begin{array}{l}\text { Continuous shrub } \\
\text { vegetation }>0.6 \mathrm{~m} \text {. } \\
(\mathrm{A}+)\end{array}$ & $\begin{array}{l}\text { Increase grazing } \\
\text { pressure, possibly } \\
\text { cutting. }\end{array}$ \\
\hline & & & $\begin{array}{l}\text { Sparse mats of }<0.3 \\
\text { m. (A-) }\end{array}$ & $\begin{array}{l}\text { Reduce grazing } \\
\text { pressure, mainly } \\
\text { cattle. }\end{array}$ \\
\hline \multirow{2}{*}{$\begin{array}{l}\text { Shrub- } \\
\text { grass ratio }\end{array}$} & \multirow{2}{*}{$\begin{array}{l}\text { Visual estimation } \\
\text { of shrub and grass } \\
\text { cover. }\end{array}$} & \multirow{2}{*}{$\begin{array}{l}\text { Shrub-grass cover } \\
\text { ratio of } 0.3-0.8 \text {. }\end{array}$} & \begin{tabular}{|l|} 
Continuous shrub \\
cover \\
$($ ratio $>0.8)$ \\
$(\mathrm{B}+)$ \\
\end{tabular} & $\begin{array}{l}\text { Cutting and } \\
\text { herding, mainly } \\
\text { ponies. }\end{array}$ \\
\hline & & & $\begin{array}{l}\text { Low shrub } \\
\text { cover }(\text { ratio }<0.3) \text {. } \\
(\text { B-) }\end{array}$ & $\begin{array}{l}\text { Reduce grazing } \\
\text { pressure, mainly } \\
\text { cattle. }\end{array}$ \\
\hline $\begin{array}{l}\text { Gorse } \\
\text { cover }\end{array}$ & $\begin{array}{l}\text { Visual estimation } \\
\text { of gorse (Ulex spp.) } \\
\text { cover. }\end{array}$ & $\begin{array}{l}\text { Gorse cover of } \\
<50 \% \text { of shrub } \\
\text { cover. }\end{array}$ & $\begin{array}{l}\text { High cover values of } \\
\text { gorse }(\geq 50 \%) \text { and } \\
\text { tall mats. (C) }\end{array}$ & $\begin{array}{l}\text { Cutting and } \\
\text { grazing by } \\
\text { ponies. }\end{array}$ \\
\hline $\begin{array}{l}\text { Bracken } \\
\text { cover }\end{array}$ & $\begin{array}{l}\text { Visual estimation of } \\
\text { bracken (Pteridium } \\
\text { aquilinum) cover. }\end{array}$ & $\begin{array}{l}\text { No presence of } \\
\text { bracken. }\end{array}$ & $\begin{array}{l}\text { Low, medium } \\
\text { or high cover of } \\
\text { bracken. }(\mathrm{D})\end{array}$ & $\begin{array}{l}\text { No action } \\
\text { required if } \\
\text { localized. }\end{array}$ \\
\hline $\begin{array}{l}\text { Exotic tree } \\
\text { species }\end{array}$ & $\begin{array}{l}\text { Density and cover } \\
\text { of exotic tree } \\
\text { species (Pinus spp. } \\
\text { or Eucalyptus). } \\
\text { Presence of saplings. }\end{array}$ & $\begin{array}{l}\text { No presence } \\
\text { of exotic tree } \\
\text { species or very } \\
\text { sparse adult trees. }\end{array}$ & $\begin{array}{l}\text { Medium density of } \\
\text { exotic tree species. } \\
\text { Regeneration by } \\
\text { saplings frequent. } \\
\text { (E) } \\
\end{array}$ & \begin{tabular}{|l} 
Cutting and \\
removing \\
saplings. Light \\
increase of \\
grazing. \\
\end{tabular} \\
\hline $\begin{array}{l}\text { Natural } \\
\text { succession }\end{array}$ & $\begin{array}{l}\text { Encroachment of } \\
\text { shrub and trees } \\
\text { (Betula pubescens, } \\
\text { Erica arborea, } \\
\text { Cytisus spp.). } \\
\end{array}$ & $\begin{array}{l}\text { Low cover }(< \\
5 \% \text { at landscape } \\
\text { scale }) \text { of trees and } \\
\text { shrub species. }\end{array}$ & $\begin{array}{l}\text { Medium or high } \\
\text { cover of trees and } \\
\text { shrub. (F) }\end{array}$ & $\begin{array}{l}\text { Cutting tall and } \\
\text { dense vegetation } \\
\text { followed by } \\
\text { increasing } \\
\text { grazing pressure. } \\
\end{array}$ \\
\hline $\begin{array}{l}\text { Erosive } \\
\text { features } \\
\text { and } \\
\text { drainage } \\
\text { problems }\end{array}$ & $\begin{array}{l}\text { Identification and } \\
\text { mapping of major } \\
\text { erosive features } \\
\text { and trampling } \\
\text { evidences. } \\
\text { Detection of off } \\
\text { road paths. } \\
\text { Identification } \\
\text { of ditches and } \\
\text { other drainage } \\
\text { infrastructures. }\end{array}$ & $\begin{array}{l}\text { No major erosive } \\
\text { features. } \\
\text { Low } \\
\text { coverage of bare } \\
\text { soil. Caused } \\
\text { by trampling } \\
(<5 \%) \text { or } \\
\text { circulation along } \\
\text { paths. Natural } \\
\text { hydrologic } \\
\text { dynamics. }\end{array}$ & $\begin{array}{l}\text { High occurrence of } \\
\text { erosive features and } \\
\text { soil compaction. } \\
\text { Changes in } \\
\text { the hydrologic } \\
\text { dynamics and } \\
\text { functions. (G) }\end{array}$ & $\begin{array}{l}\text { Decrease of } \\
\text { grazing pressure. } \\
\text { Fencing of areas } \\
\text { with high erosion. } \\
\text { Signals or obstacles } \\
\text { on paths. Habitat } \\
\text { restoration through } \\
\text { recovery of the } \\
\text { original hydrologic } \\
\text { dynamics (e.g. } \\
\text { by occlusion of } \\
\text { ditches). }\end{array}$ \\
\hline
\end{tabular}




\subsection{Setting a Habitat Quality Assessment (HQA) system}

According to the items described, a scoring system is proposed to integrate them into a single matrix. Heathland stands are evaluated for each item, thus final scores correspond to the number of items with an optimum value, ranging from zero (transformed heaths) to seven (the optimum state, Table 2). Other items like species richness and diversity were not included in the final protocol for HQA because they are complex to evaluate by non-technical personnel. Occurrence of rare species can vary naturally among sites, thus establishing a closed list of rare species to be included as positive signals of habitat quality is not recommended (JNCC, 2004). Similarly, indicators such as presence of the small invasive moss Campylopus introflexus requires training and small-scale assessment, which is undesirable for a method that must cover large stands with a single score.

Each item receives a score of one for the optimum status and a score of zero for the alternative status. If the optimum status is not reached, then an alphabetic code indicates the habitat quality item, which fails to reach the optimum. We propose a HQA index composed by a quality score followed by an alphabetic code (A+/-, B+/-, $\mathrm{C}, \mathrm{D}, \mathrm{E}, \mathrm{F}, \mathrm{G})$. The score is calculated as the sum of the number of items in an optimun value. The alphabetic code indicates items which does not reach the optimum and first and second items show a sign $+/$ - depending on whether height of shrub mats or shrub grass ratio are higher or lower than the optimum value respectively. Heavily transformed areas as improved pastures or pine plantation stands are given a score of zero.

\subsection{Study area}

We have selected a study area to test the application of the HQA within the Serra do Xistral Natura 2000 Site. This Special Conservation Site is located in the north of Galicia, NW Spain. Among other priority habitats, it holds a good representation of E. mackayana Atlantic wet heaths associated to traditional use of free-ranging cattle and wild ponies. This site comprises several communal land properties or Montes Vecinales en Man Común (MMVMC), owned by local commoners with common rights of use. The MMVMC comprises 1300.8 ha with an altitudinal range between 680 and $1027 \mathrm{~m}$.

First, Sentinel-2 multitemporal and multispectral remote sensing images (European Space Agency, 2018), corresponding with different phenological stages, were classified using object-oriented analyses including machine learning algorithms and classification rules to obtain a $20 \mathrm{~m}$ spatial resolution land cover reference. This information was subsequently used in a fine-scale manual classification based in digital orthophotomosaic (PNOA, (C) Instituto Geográfico Nacional. CNIG, 2018) photointerpretation and field work to build a habitat map, adapting the Habitat directive classification for natural and semi-natural habitats and EUNIS (European Environment Agency, 2018). Eleven habitats were identified within the study area (Fig. 1). Pine plantations and improved pastures were considered transformed wet heaths. 


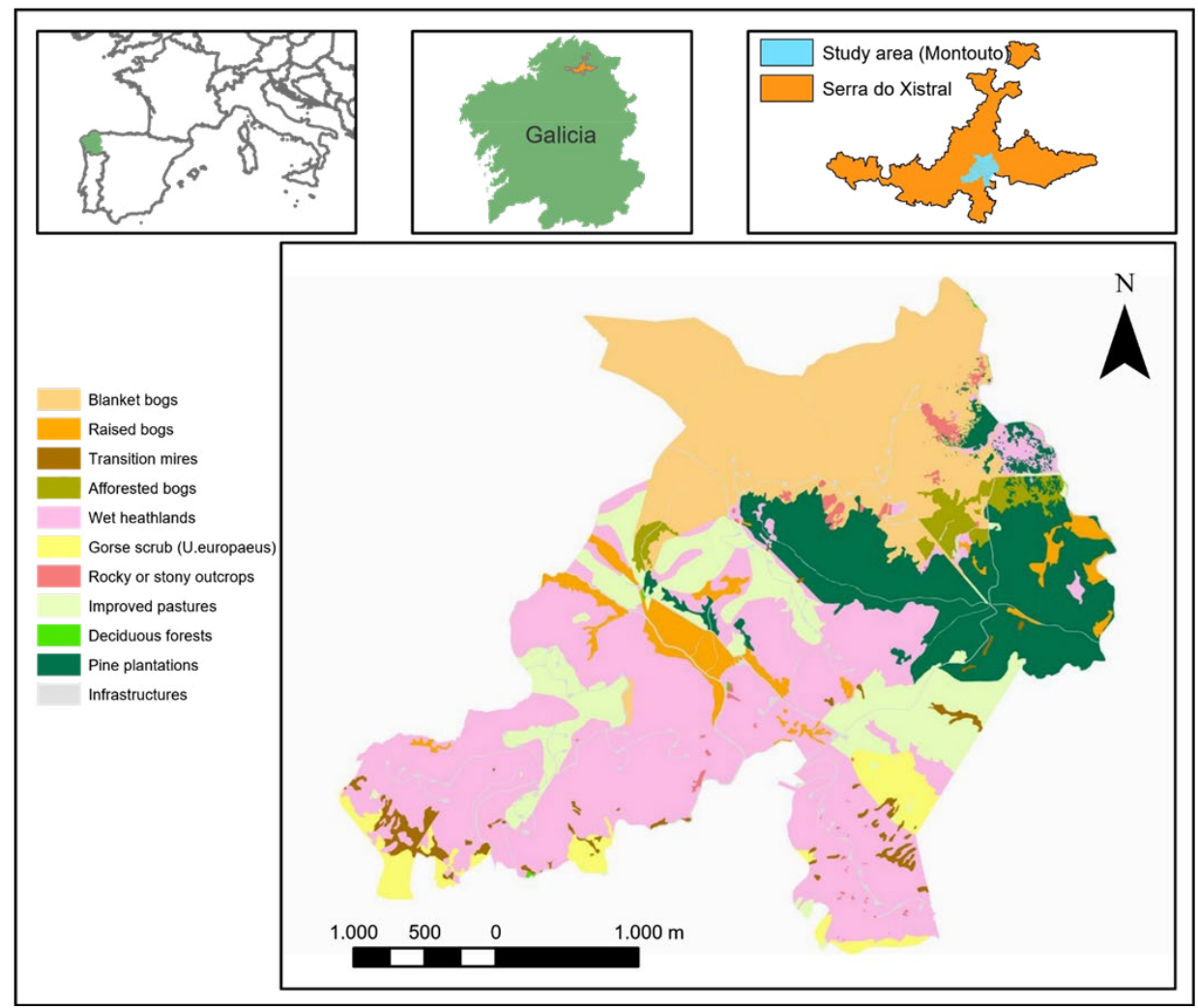

Figure 1. Map of the study area showing the different habitats and land uses.

Then, we established a coarse division of the area in mapping units to apply the HQA. According to a regional law, common land properties of over 25 ha must develop a Forest Management Plan (FMP). In this plan, the land is divided in inventory units or cantón. We thus propose the cantón as the mapping unit for the assessment of habitat quality by owners in communal lands. A cantón may vary between 5 and 50 ha, its size depends on the ecological heterogeneity of the land and the intensity of management (de la Hoz, 2004).

Wet heaths (Habitats Directive code 4020*) and blanket bogs $(7130 *$ ) are the most represented habitats (Table 3 ). Other habitats considered in the Habitats Directive are raised bogs $\left(7110^{*}\right)$ and transition mires (7140). Transformed land includes infrastructures such as paved roads and wind farms facilities. Improved pastures and pine plantations, considered here as potential areas to restore heathlands, were also important. Deciduous forest and rocky or stony outcrops are marginally represented. 
Table 3. Habitats and land uses in the study area including total occupancy area and percentage cover.

\begin{tabular}{|l|r|r|}
\hline \multicolumn{1}{|c|}{ Habitat } & Area (ha) & \multicolumn{1}{c|}{$\begin{array}{c}\text { Cover } \\
(\%)\end{array}$} \\
\hline Bogs & 388.9 & 29.9 \\
Blanket bogs & 297.6 & 22.9 \\
Raised bogs & 47.2 & 3.6 \\
Transition mires & 18.7 & 1.4 \\
Afforested bogs & 25.4 & 2.0 \\
\hline Heathland and shrub & 528.4 & 40.6 \\
Wet heaths & 482.3 & 37.1 \\
Gorse shrub (with Ulex europaeus) & 46.1 & 3.5 \\
\hline Improved pastures & 146.2 & 11.2 \\
\hline Pine plantations & 196.9 & 15.1 \\
\hline Deciduous forests & 0.7 & 0.1 \\
\hline Rocky or stony outcrops & 9.5 & 0.7 \\
\hline Infrastructures & 30.3 & 2.3 \\
\hline Total & 1300.8 & 100.0 \\
\hline
\end{tabular}

\section{Results}

Wet heaths covered 482.3 ha, which represents $37.1 \%$ of the study area (Table 3, Fig. 2). In addition, improved pastures (146.2 ha, 11.2\%) and pine plantations (196.9 ha, $15.1 \%$ ) are considered as potentially covered by wet heaths. Small patches ( $<5$ ha) of transition mires, bogs and rocky outcrops within large heath stands are also considered for evaluation as part of the heathland complex, giving a total of 865.17 ha to be evaluated with the HQA system. Both improved pastures and pine plantations scored 0 because they are heavily transformed and key species such as $E$. mackayana are absent. Therefore, score 0 is the most represented value, up to $40 \%$ of the evaluated heathland area (Table 4 ). $7.02 \%$ of the wet heaths were identified as patches in an optimum condition (Table 4). Stands with a lower score ranged from very good (score 6) to poor quality (score 2 ). The different measured items contributed unequally to lower the score of the heath stands. Those with a very good status (score 6; 28.3\%) showed, to a large extent, high gorse cover (code C) or natural succession issues (code F). Others reached a good status (score $5 ; 18.6 \%$ ) because they had high gorse cover and high cover of shrubs $(B+C)$, or obvious erosive features (CG). The remaining stands with lower habitat quality (score 4, 3 or 2) cover less than $5 \%$ of the evaluated heathland area. Examples of stands with different HQA scores are shown in Figure 3. 
Table 4. Habitat Quality Assessment scores and codes for wet heaths at the study area. The scores range from 7 , for heaths classified as in an optimum status, to 0 , for transformed heaths.

The code indicates the score and the item or items that failed to reach the optimum status: vegetation structure $(A)$, shrub-grass ratio $(B)$, gorse cover $(C)$, bracken cover $(D)$, exotic tree species $(E)$, natural succession $(F)$, erosive features and drainage problems $(G)$.

\begin{tabular}{|c|c|c|c|c|c|}
\hline Score & Code & & Description & $\begin{array}{c}\text { Area } \\
\text { (ha) }\end{array}$ & $\begin{array}{c}\text { Cover } \\
(\%)\end{array}$ \\
\hline 7 & 7 & Optimum & & 60.70 & 7.02 \\
\hline \multirow[t]{6}{*}{6} & $6 \mathrm{~A}-$ & \multirow[b]{6}{*}{ Very good } & - with low shrub height $(<0.3 \mathrm{~m})$ & 16.58 & 1.92 \\
\hline & $6 \mathrm{~B}-$ & & - with low shrub-grass ratio $(<0.3)$ & 8.38 & 0.97 \\
\hline & $6 \mathrm{C}$ & & - with high gorse cover $(\geq 50 \%)$ & 116.52 & 13.47 \\
\hline & $6 \mathrm{~F}$ & & - with evidence of natural succession & 97.24 & 11.24 \\
\hline & $6 \mathrm{G}$ & & - with evidence of erosive events or drainage issues & 5.81 & 0.67 \\
\hline & $\begin{array}{l}6 \text { (all } \\
\text { types) }\end{array}$ & & & 244.5 & 28.3 \\
\hline \multirow[t]{8}{*}{5} & $5 \mathrm{~A}-\mathrm{B}-$ & \multirow[b]{8}{*}{ Good } & $\begin{array}{l}\text { - with low shrub height }(<0.3 \mathrm{~m}) \text { and low shrub-grass } \\
\text { ratio }(<0.3)\end{array}$ & 8.18 & 0.95 \\
\hline & $5 \mathrm{~A}-\mathrm{F}$ & & $\begin{array}{l}\text { - with low shrub height }(<0.3 \mathrm{~m}) \text { and evidence of } \\
\text { natural succession }\end{array}$ & 1.65 & 0.19 \\
\hline & $5 \mathrm{~A}-\mathrm{G}$ & & $\begin{array}{l}\text { - with low shrub height }(<0.3 \mathrm{~m}) \text { and evidence of } \\
\text { erosive events or drainage issues }\end{array}$ & 20.87 & 2.41 \\
\hline & $5 \mathrm{~B}+\mathrm{C}$ & & $\begin{array}{l}\text { - with high shrub-grass ratio }(>0.8) \text { and high gorse } \\
\text { cover } \\
(\geq 50 \%)\end{array}$ & 68.06 & 7.87 \\
\hline & $5 \mathrm{~B}-\mathrm{G}$ & & $\begin{array}{l}\text { - with low shrub-grass ratio }(<0.3) \text { and evidence of } \\
\text { erosive events or drainage issues }\end{array}$ & 3.02 & 0.35 \\
\hline & $5 \mathrm{CG}$ & & $\begin{array}{l}\text { - with high gorse cover ( } \geq 50 \%) \text { and evidence of } \\
\text { erosive events or drainage issues }\end{array}$ & 55.83 & 6.45 \\
\hline & $5 \mathrm{FG}$ & & $\begin{array}{l}\text { - with evidence of natural succession and evidence of } \\
\text { erosive events or drainage issues }\end{array}$ & 2.87 & 0.33 \\
\hline & $\begin{array}{l}5 \text { (all } \\
\text { types) }\end{array}$ & & & 160.5 & 18.6 \\
\hline \multirow[t]{6}{*}{4} & $4 \mathrm{~A}-\mathrm{B}-\mathrm{C}$ & & $\begin{array}{l}\text { - with low shrub height }(<0.3 \mathrm{~m}) \text {, low shrub-grass ratio } \\
(<0.3) \text { and high gorse cover }(\geq 50 \%)\end{array}$ & 1.07 & 0.12 \\
\hline & $4 A+B+C$ & & $\begin{array}{l}\text { - with large shrub height }(>0.6 \mathrm{~m}) \text {, high shrub-grass ratio } \\
(>0.8) \text { and high gorse cover }(\geq 50 \%)\end{array}$ & 3.99 & 0.46 \\
\hline & $4 A+B+F$ & & $\begin{array}{l}\text { - with large shrub height }(>0.6 \mathrm{~m}) \text {, high shrub-grass ratio } \\
(>0.8) \text { and evidence of natural succession }\end{array}$ & 1.82 & 0.21 \\
\hline & 4B-CD & & $\begin{array}{l}\text { - with low shrub-grass ratio }(<0.3) \text {, high gorse cover } \\
(\geq 50 \%) \text { and presence of bracken }\end{array}$ & 2.57 & 0.30 \\
\hline & $4 B+C F$ & & $\begin{array}{l}\text { - with high shrub-grass ratio }(>0.8) \text {, high gorse cover } \\
(\geq 50 \%) \text { and evidence of natural succession }\end{array}$ & 0.11 & 0.001 \\
\hline & $4 \mathrm{~B}+\mathrm{CG}$ & & $\begin{array}{l}\text { - with high shrub-grass ratio }(>0.8) \text {, high gorse cover } \\
(\geq 50 \%) \text { and evidence of erosive events or drainage } \\
\text { issues }\end{array}$ & 40.53 & 4.68 \\
\hline
\end{tabular}




\begin{tabular}{|c|c|c|c|c|c|}
\hline Score & Code & & Description & $\begin{array}{c}\text { Area } \\
\text { (ha) }\end{array}$ & $\begin{array}{c}\text { Cover } \\
(\%)\end{array}$ \\
\hline & 4B-FG & & $\begin{array}{l}\text { - with low shrub-grass ratio }(<0.3) \text {, evidence of } \\
\text { natural succession and evidence of erosive events or } \\
\text { drainage issues }\end{array}$ & 0.73 & 0.08 \\
\hline & 4 (all types) & Medium & & 50.8 & 5.9 \\
\hline 3 & $3 \mathrm{~A}+\mathrm{B}+\mathrm{CD}$ & Poor & $\begin{array}{l}\text { - with large shrub height }(>0.6 \mathrm{~m}) \text {, high shrub-grass ratio } \\
(>0.8) \text {,. high gorse cover }(\geq 50 \%) \text { and presence of } \\
\text { bracken }\end{array}$ & 0.56 & 0.07 \\
\hline 2 & $\begin{array}{c}2 \mathrm{~A}+\mathrm{B}- \\
\mathrm{CFG}\end{array}$ & $\mathrm{Bad}$ & $\begin{array}{l}\text { - with large shrub height }(>0.6 \mathrm{~m}) \text {, low shrub-grass ratio } \\
(<0.3) \text {, high gorse cover }(\geq 50 \%) \text {, evidence of natural } \\
\text { succession and evidence of erosive events or drainage } \\
\text { issues }\end{array}$ & 0.42 & 0.05 \\
\hline & $2 \mathrm{~A}+\mathrm{B}+\mathrm{CFG}$ & & $\begin{array}{l}\text { - with large shrub height }(>0.6 \mathrm{~m}) \text {, high shrub-grass } \\
\text { ratio }(>0.8) \text {, high gorse cover }(\geq 50 \%) \text {, evidence of } \\
\text { natural succession and evidence of erosive events or } \\
\text { drainage issues }\end{array}$ & 0.51 & 0.06 \\
\hline 0 & 0 & & $\begin{array}{l}\text { Heaths severely transformed to improved pastures or } \\
\text { to pine plantation stands }\end{array}$ & 347.13 & 40.12 \\
\hline Total & & & & 865.17 & 100.00 \\
\hline
\end{tabular}

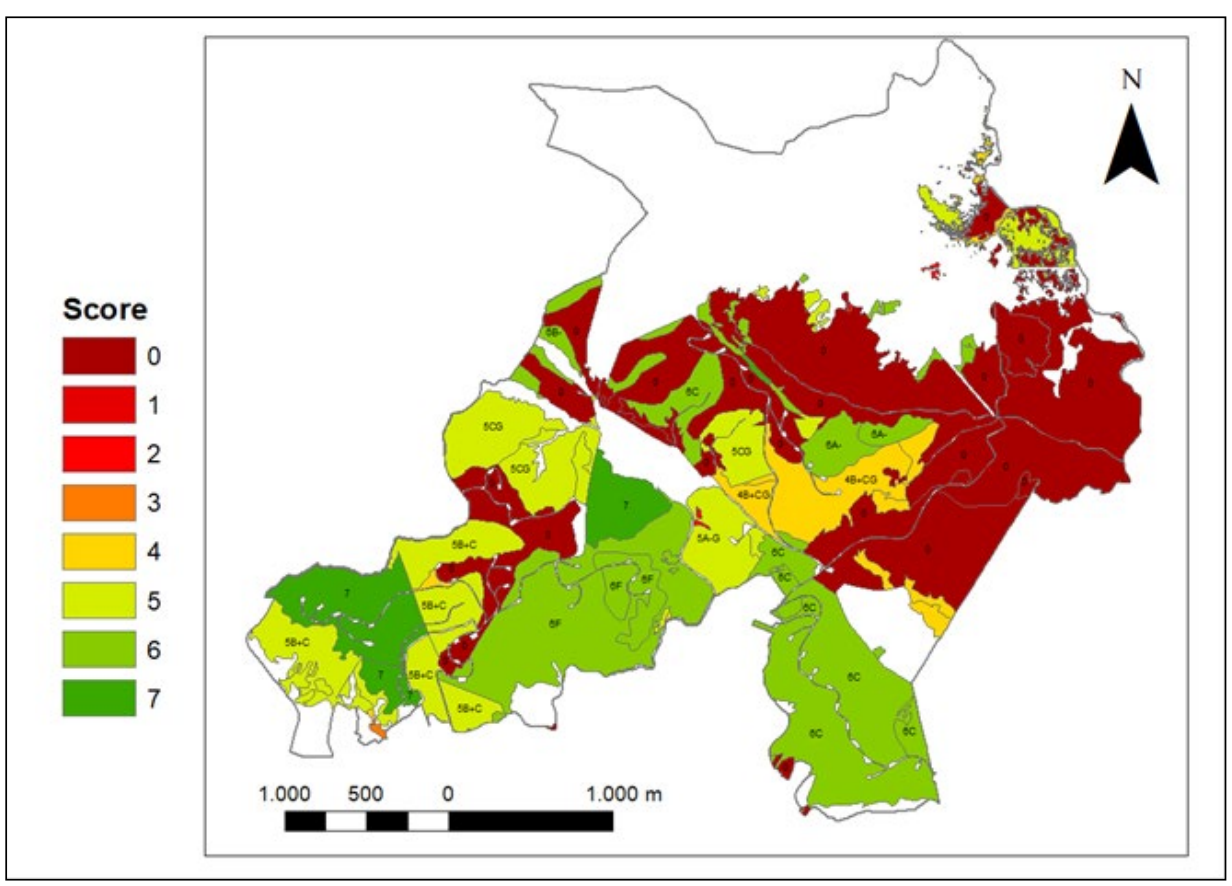

Figure 2. Habitat Quality Assessment in the study area showing the quality score and code. 

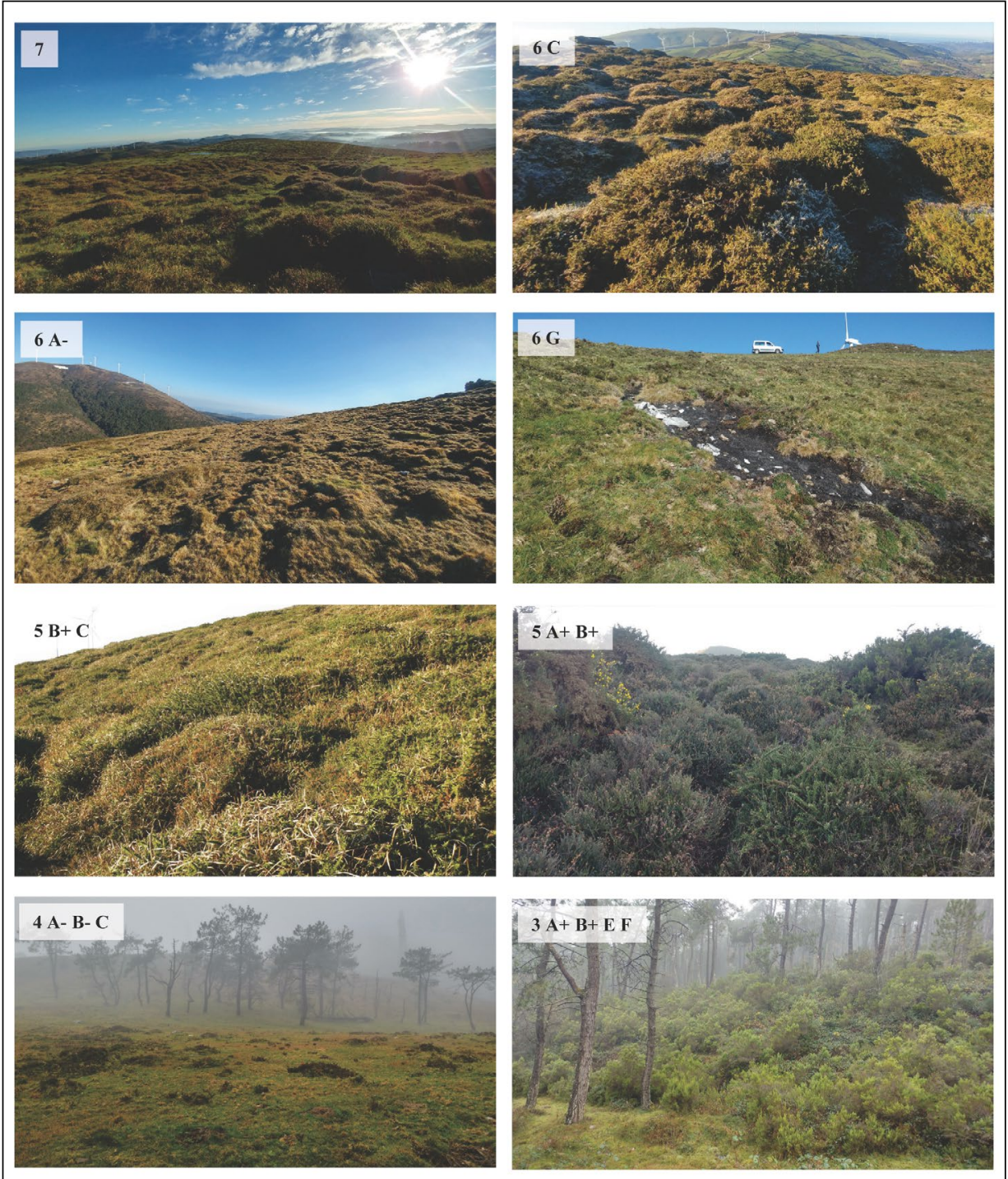

Figure 3. Examples of heath stands with different HQA scores. (7) optimum state; (6 C) very good habitat quality with high gorse cover; (6A-) very good habitat quality with shrub height $<0.3 \mathrm{~m} ;(6 \mathrm{G})$ very good habitat quality with recognized erosive events; $(5 B+C)$ good habitat quality with high shrub-grass ratio and gorse cover; $(5 A+B+)$ good habitat quality with high canopy and shrub-grass ratio; $(4 A-B-C)$ medium habitat quality which fails due to vegetation structure, shrub-grass ratio and gorse cover; $(3 A+B+E F)$ medium habitat quality which fails due to vegetation structure, shrub-grass ratio, natural succession showing high cover of shrub and presence of pines. 


\section{Discussion}

\subsection{Methodological approach}

Different approaches have been considered in establishing feasible HQA systems, depending on the complexity of the target habitat and the main objectives of the evaluation (Gibbons and Freudenberger, 2006). It should be noted that the term "habitat" has been applied in different ways (Garshelis, 2000). From a specific approach, the habitat is the environment in which a species can occur and performs its ordinary living. This approach, generally used for plants or animals, describes the abiotic and biotic factors that best explain the conditions where a given species occurs (Hall et al., 1997). A different definition for habitat is the description of a reasonably homogeneous environment, regardless of the occurrence of any single species that may occur in such environment (Garshelis, 2000). Therefore, in the former definition, habitat is always considered an intrinsic characteristic of a species, whilst in the later, it describes a certain environment where different species may occur. In the EU Habitats directive, the term habitat applies mainly to vegetation types, such as grasslands, shrublands or different types of forests. Accordingly, here we assume the EU interpretation; therefore, HQA is used in a broad sense to explain the status of vegetation stands regards cover, structure, composition and diversity. This method has similarities with the "vegetation condition" approach commonly used in Australia (Tehrany et al., 2017), with the description of common standards for vegetation types as is routinely evaluated in the UK (JNCC, 2004), or with the Floristic Quality Assessment (FQA) implemented for prairies and wetlands of NorthCentral U.S. (Bried et al., 2013).

Previous methods in literature show different constrains that prevented us from applying them directly in our study case. For example, FQA is based on a detailed floristic survey, which can only be done by trained technicians (Bried et al., 2013). Such methodology would be unaffordable for large areas. Moreover, landowners might be sceptical because they would not be able to check the assigned scores. On the other side, the vegetation condition approach considers, as a general reference, the naturalness of the vegetation as a measure of departure from the target condition (Tehrany et al., 2017). However, many European vegetation types, such as wet heaths, are shaped and maintained by human intervention. In this system, the optimum is reached in appropriately managed heaths, which prevent from an undesirable "naturalization" of the vegetation.

The development of common standards for monitoring vegetation, specifically for wet heaths (JNCC, 2004), uses a similar approach to ours. General conditions and frequent species are used as indicators and, therefore, as surrogates of habitat quality. Rare species are avoided, except in specific stands where a particular species has been recorded. In that case, a specific monitoring of the population trend is required. Similarly, indicators such as the presence of the exotic moss Campylopus introflexus requires training and small-scale assessment, which is undesirable for a method that covers large stands with a single score. Therefore, we used a functional approach and recorded vegetation structural measures as surrogates of habitat quality (Gibbons and Freudenberger, 2006). 
The use of remote sensing also emerged as a valuable approach not only for habitat mapping, but also for spatially explicit habitat quality assessment over large areas, including datasets from different sensors ranging from optical (RGB, multi- spectral and hyperspectral) imagery, to products with 3D information from LiDAR, or Structure from Motion (SfM) point clouds (Corbane et al., 2015; Díaz Varela et al., 2018). In the present work, the use of multispectral/multitemporal imagery was particularly useful in the identification of seasonal (phenologic) differences in the spectral response of certain types of habitats, e.g. for the discrimination between bogs and wet heaths. Potential improvements of the method might be obtained by the integration of datasets with information on the vegetation structure, like LiDAR or SfM point clouds or the integration of ultra high-resolution imagery obtained from sensors on board of Remotely Piloted Aircraft Systems (Michez et al., 2016). Our objectives include the development of a remote, automatic system to perform HQA minimizing costs.

By multiplying the scores by habitat area, other methods give higher values to large areas and penalize small patches with lower values (Parkes et al., 2003). However, isolated remnants of heathlands may harvest focal species and keep good habitat conditions. In addition, they can play a major role to facilitate connectivity between areas. Our HQA does not depend on the area of the habitat (McCarthy et al., 2004), leaving open the possibility of applying payment schemes based on conservation results, where payment to owners are calculated considering the area and quality score of each stand.

Another potential problem in addressing HQA is the selection of the potential area covered by the target habitat. In our system, pine tree plantations and improved pastures in a similar altitudinal range are considered to be potentially covered by wet heaths. Therefore, such mapping units with a zero score are suitable areas for habitat restoration. On the other hand, the limits between wet heathlands and blanket bogs or other types of bogs are often diffuse. E. mackayana and, less frequently, C. vulgaris, may also occur in bogs, growing at lower densities and reaching lower plant heights, and there are other species shared between both habitats. HQA for blanket bogs will be developed in a forthcoming study, but habitat boundaries should be establish with caution. Accordingly, HQA should focus on similar items to avoid inconsistencies due to divergent scores between similar communities.

Establishing a reliable HQA system is crucial to evaluate potential shifts in habitat conditions in protected areas, especially when those habitats are subjected to management practices that are needed to maintain the optimum conditions. Wet heathlands in the Xistral mountains are continuously grazed by cattle and wild ponies, less frequently by sheep. Therefore, setting an appropriate grazing pressure is crucial to maintain the habitat in the optimum state. Further evaluation is needed to calculate herbivore density for conservation means.

\subsection{Habitat quality of wet heaths in the Xistral mountains. Management for conservation}

Most wet heaths of our study area were recognized as in a good, very good or optimum state. However, several items showed alternative states in many stands, most 
of them can be corrected by management. For example, gorse cover can be reduced by increasing the number of wild ponies, which are known to feed on and control gorse (Aldezabal et al., 2013). Similarly, natural succession occurs when grazing is abandoned, what can be mitigated by favouring the presence of large herbivores. Managing for other problems such as bracken invasions may be more complex and require focused solutions, but bracken had a marginal importance in our area.

\section{Conclusions}

This study aimed to develop a quantitative method of Habitat Quality Assessment for the Atlantic wet heathlands of the Serra do Xistral protected area in Galicia, NW Spain. The method, based on the definition of an optimum state and the alternative states that may arise from habitat degradation, is, to our knowledge, the first of its kind for monitoring Habitat Quality of Atlantic wet heaths, a priority habitat for the European Union. This method considers indirect indicators of vegetation cover, structure, and several functional groups, that are known to correlate with other values like rare species diversity. This is a first step for i) the development of a remote sensing image analysis for HQA, and ii) the potential implementation of a payment scheme based on habitat conservation. These major challenges may be a starting point for a shift in conservation policies, which should include farmers and landowners as key actors in the preservation of such invaluable habitats.

\section{Acknowledgements}

This study was financed by the EU LIFE+ program through the LIFE IN COMMON LAND project (LIFE16 NAT/ES/000707).

\section{References}

Aldezabal, A., Mandaluniz, N., Laskurain, N.A. 2013. Gorse (Ulex spp.) use by ponies in winter: Is the spatial pattern of browsing independent of the neighbouring vegetation? Grass and Forage Science 68, 49-58. https://doi.org/10.1111/j.1365-2494.2012.00865.x.

Alonso, I., Härdtle, W. 2015. Resolving potential conflicts between different heathland ecosystem services through adaptive management. Ecological Questions 21, 101-103. http://doi. org/10.12775/EQ.2015.017.

Bárcena, F. 2012. Garranos: Os póneis selvagens (Equus ferus sp.) do norte da Península Ibérica. In: Livro de Atas, I Congresso Internacional do Garrano, Arcos de Valdevez, 23-25 september 2011, pp. 75-96.

Bokdam, J., Gleichman, J.M. 2000. Effects of grazing by free-ranging cattle on vegetation dynamics in a continental north-west European heathland. Journal of Applied Ecology 37, 415-431. https://doi.org/10.1046/j.1365-2664.2000.00507.x.

Bried, J.T., Jog, S.K., Matthews, J.W. 2013. Floristic quality assessment signals human disturbance over natural variability in a wetland system. Ecological indicators 34, 260-267. https://doi. org/10.1016/j.ecolind.2013.05.012.

CNIG (Centro Nacional de Información Geográfica) 2018. PNOA Ortophotos. Avaliable at: http://centrodedescargas.cnig.es/CentroDescargas/catalogo.do?Serie=INTMI (last access: 24/10/2018). 
Consellería de Medio Ambiente, Territorio e Vivienda 2018. Serra do Xistral. Avaliable at: https:// cmaot.xunta.gal/seccion-tema/c/Conservacion?content=Direccion_Xeral_Conservacion_ Natureza/Espazos_protexidos/seccion.html\&sub=Rede_natura_2000/\&ui=Direccion_ Xeral_Conservacion_Natureza/Dinamico/Lic/lic_0055.html (last access: 23/10/2018).

Corbane, C., Lang, S., Pipkins, K., Alleaume, S., Deshayes, M., García Millán, V.E., Strasser, T., Vanden Borre, J., Toon, S., Michael, F. 2015. Remote sensing for mapping natural habitats and their conservation status - New opportunities and challenges. International Journal of Applied Earth Observation and Geoinformation 37, 7-16. https://doi.org/10.1016/j. jag.2014.11.005.

Cordingley, J.E., Newton, A.C., Rose, R.J., Clarke, R.T., Bullock, J.M. 2015. Habitat fragmentation intensifies trade-offs between biodiversity and ecosystem services in a heathland ecosystem in southern England. PloS One 10 (6), e0130004.https://doi.org/10.1371/journal.pone.0130004.

de la Hoz, F.M., Oliet, J.A., Abellanas, O.B., Cuadros, S., Fernández, P., Zamora, R. 2004. Manual de ordenación de montes de Andalucía. Consejería de medio Ambiente de la Junta de Andalucía, Sevilla, 365 pp.

Díaz-Varela, R.A., Iglesias, S.C., Castro, C.C., Varela, E.D. 2018. Sub-metric analisis of vegetation structure in bog-heathland mosaics using very high resolution rpas imagery. Ecological Indicators 89, 861-873. https://doi.org/10.1016/j.ecolind.2017.11.068.

European Environment Agency (EEA) 2018. EUNIS habitat classification. Available at: https://www.eea.europa.eu/data-and-maps/data/eunis-habitat-classification (last access: 05/06/2018).

European Space Agency (ESA) 2018. Sentinel Data Products of the Copernicus Data and Information Access Service. Available at: https://sentinel.esa.int/web/sentinel/sentinel-dataaccess (last access: 24/10/2018).

Fagúndez, J. 2013. Heathlands confronting global change: drivers of biodiversity loss from past to future scenarios. Annals of Botany 111 (2), 151-172. https://doi.org/10.1093/aob/mcs257.

Fagúndez, J. 2016. Grazing effects on plant diversity in the endemic Erica mackayana heathland community of north-west Spain. Plant Ecology \& Diversity 9 (2), 207-217. https://doi.org/1 0.1080/17550874.2016.1191555.

Fagúndez, J. 2018. Canopy height and competition explain species segregation in wet heathlands. Journal of Vegetation Science 29, 765-774. https://doi.org/10.1111/jvs.12661.

García, R.R., Fraser, M.D., Celaya, R., Ferreira, L.M.M., García, U., Osoro, K. 2013. Grazing land management and biodiversity in the Atlantic European heathlands: a review. Agroforestry Systems 87(1), 19-43. https://doi.org/10.1007/s10457-012-9519-3.

Garshelis, D.L. 2000. Delusions in habitat evaluation: measuring use, selection, and importance. In: L. Boitani, T.K. Fuller (Eds.) Research techniques in animal ecology: controversies and consequences. Columbia University Press, New York, pp. 111-164.

Gibbons, P., Freudenberger, D. 2006. An overview of methods used to assess vegetation condition at the scale of the site. Ecological Management \& Restoration 7, 10-17. https://doi. org/10.1111/j.1442-8903.2006.00286.x.

Gimingham, C.H. 1975. An introduction to heathland ecology. Oliver \& Boyd, Edinburgh, 124 pp.

Hall, L.S., Krausman, P.R., Morrison, M.L. 1997. The habitat concept and a plea for standard terminology. Wildlife Society Bulletin 25, 173-182.

Hellawell, J.M. 1991. Development of a rationale for monitoring. In: F.B. Goldsmith (Ed.), Monitoring for Conservation and Ecology. Springer Netherlands, Dordrecht, pp. 1-14.

Holden, J., Shotbolt, L., Bonn, A., Burt, T.P., Chapman, P.J., Dougill, A.J., Fraser, E.D.G., Hubacek, K., Irvine, B., Kirkby, M.J., Reed, M.S., Prell, C., Stagl, S., Stringer, L.C., Turner, A., Worrall, F. 2007. Environmental change in moorland landscapes. Earth-Science Reviews 82, 75-100. https://doi.org/10.1016/j.earscirev.2007.01.003. 
Hooftman, D. A., Edwards, B., Bullock, J. M. 2016. Reductions in connectivity and habitat quality drive local extinctions in a plant diversity hotspot. Ecography 39 (6), 583-592. https://doi. org/10.1111/ecog.01503.

Iglesia, P. 1973. Los caballos gallegos explotados en régimen de libertad o caballos salvajes de Galicia. Universidad Complutense de Madrid, Facultad de Veterinaria, 1.205 pp.

JNCC (Joint Nature Conservation Committee) 2004. Common Standards for Monitoring Guidance Lowland Heathland. Petersborough, U.K.

Lagos, L. 2013. Ecología del lobo (Canis lupus), del poni salvaje (Equus ferus atlanticus) y del ganado vacuno semiextensivo (Bos taurus) en Galicia: interacciones depredador-presa. Ph.D Thesis. Universidad de Santiago de Compostela, Santiago de Compostela, 458 pp.

Loidi, J., Biurrun, I., Campos, J.A., García-Mijangos, I., Herrera, M. 2010. A biogeographical analysis of the European Atlantic lowland heathlands. Journal of Vegetation Science 21 (5), 832-842. https://doi.org/10.1111/j.1654-1103.2010.01204.x.

Marrs, R.H., 1987. Studies on the Conservation of Lowland Calluna Heaths. I. Control of Birch and Bracken and its Effect on Heath Vegetation. Journal of Applied Ecology 24, 163-175. https://doi.org/10.2307/2403795.

Marrs, R.H., Hicks, M.J., Fuller, R.M. 1986. Losses of lowland heath through succession at four sites in Breckland, East Anglia, England. Biological Conservation 36, 19-38. https://doi. org/10.1016/0006-3207(86)90099-6.

McCarthy, M.A., Parris, K.M., Van Der Ree, R., McDonnell, M.J., Burgman, M.A., Williams, N.S.G., McLean, N., Harper, M.J., Meyer, R., Hahs, A., Coates, T. 2004. The habitat hectares approach to vegetation assessment: an evaluation and suggestions for improvement. Ecological Management \& Restoration 5 (1), 24-27. https://doi.org/10.1111/j.14428903.2004.00173.x.

Michez, A., Piégay, H., Lisein, J., Claessens, H., Lejeune, P., 2016. Classification of riparian forest species and health condition using multi-temporal and hyperspatial imagery from unmanned aerial system. Environmental Monitoring and Assessment 188, 146. https://doi.org/10.1007/ s10661-015-4996-2.

Morán-Ordóñez, A., Bugter, R., Suárez-Seoane, S., de Luis, E., Calvo, L. 2013. Temporal changes in socio-ecological systems and their impact on ecosystem services at different governance scales: a case study of heathlands. Ecosystems 16 (5), 765-782. https://doi.org/10.1007/ s10021-013-9649-0.

Nuñez, C., Scorolli, A., Lagos, L., Berman, D., Kane, A. 2016. Management of free-roaming horses. In: J.I. Ransom, P. Kaczensky (Eds.) Wild equids. Ecology, management, and conservation. Johns Hopkins University Press, Baltimore, pp. 133-148.

Parkes, D., Newell, G., Cheal, D. 2003. Assessing the quality of native vegetation: the 'habitat hectares' approach. Ecological Management \& Restoration 4, 29-38. https://doi.org/10.1046/ j.1442-8903.4.s.4.x.

Pywell, R.F., Meek, W.R., Webb, N.R., Putwain, P.D., Bullock, J.M. 2011. Long-term heathland restoration on former grassland: the results of a 17-year experiment. Biological Conservation 144 (5), 1602-1609. https://doi.org/10.1016/j.biocon.2011.02.010.

Tehrany, M.S., Kumar, L., Drielsma, M.J. 2017. Review of native vegetation condition assessment concepts, methods and future trends. Journal for Nature Conservation 40, 12-23. https://doi. org/10.1016/j.jnc.2017.08.004.

Vandvik, V., Heegaard, E., Maren, I.E., Aarrestad, P.A., 2005. Managing heterogeneity: the importance of grazing and environmental variation on post-fire succession in heathlands. Journal of Applied Ecology 42, 139-149. https://doi.org/10.1111/j.1365-2664.2005.00982.x.

Webb, N.R. 1998. The traditional management of European heathlands. Journal of Applied Ecology 35 (6), 987-990. https://doi.org/10.1111/j.1365-2664.1998.tb00020.x. 